\title{
Implementation of Advanced Product Quality Planning In Engineering Project
}

\author{
Aditya M. Deshpande ${ }^{1}$, Siddhalingeshwar I. G. ${ }^{2}$, Nagaraj Ekabote ${ }^{3}$ \\ ${ }^{1}$ Department of Automobile Engineering, B.V.B.C.E.T., Hubballi \\ ${ }^{2}$ Department of Automobile Engineering, B.V.B.C.E.T., Hubballi \\ 1aditya@bvb.edu \\ 2igs@bvb.edu
}

\begin{abstract}
Engineering Design (ED) process is the foundation on which Automobile Engineering students currently base their project work. Though efficient in addressing the primary academic requirements, it is nevertheless open ended and hence the methodology for project execution will differ from team to team. ED at higher semesters, in the author's perspective, is less structured and feel there is a need for a defined industrial methodology based on ED, especially to address the needs of automobile engineering students.
\end{abstract}

This requirement can be fulfilled by Advanced Product Quality Planning (APQP), a framework of procedures and techniques followed by the automotive industry worldwide.

An attempt was made to implement APQP on experimental basis in a project titled Solar Array Electric Vehicle. The following four stages were incorporated in the project: Plan and Define Program, Product Design and Development, Feedback and Corrective actions and Control Plan Methodology. This paper highlights the scope, implementation methodology and results of application of APQP in Solar Array Electric Vehicle project.

Key words: Engineering Design, APQP, Solar Array Electric Vehicle.

Aditya M. Deshpande

Department of Automobile Engineering, B. V. Bhoomaraddi College of Engineering and

Technology, Vidyanagar, Hubli - 580031

aditya@bvb.edu

\section{Introduction}

Advanced Product Quality Planning (APQP) is a framework of procedures and techniques used to develop products in industry, particularly the automotive industry. It is a structured method for defining and establishing steps for a product development system for General Motors, Ford, Chrysler and their suppliers [APQP Reference Manual, 1995]. APQP supports the development of a product and product quality plan to meet the needs of internal and external customers.

APQP is comprised of one pre-planning stage and five concurrent, collaborative sections. This process is represented in a continuous cycle and is often illustrated with the Plan, Do, Study, Act Cycle. Each section has a logical sequence of analytical techniques and tools used to discover risk and weakness. APQP team members are cross functional, able to identify each risk, and take actions to reduce or eliminate the potential failure [APQP Reference Manual, 1995].

\section{Six Sections of APQP:}

1. Plan and Define

2. Product Design and Development

3. Process Design and Development

4. Product and Process Validation

5. Feedback, Assessment and Corrective Action

6. Control Plan Methodology

Each section has inputs, outputs and gateway reviews with management. Gateways are timed to coincide with key decisions impacting project Quality, Cost or Delivery. APQP culminates in a sample submission as evidence that the product quality, as planned, was achieved. This activity is called PPAP (Product Part Approval Process). PPAP highlights the proof or evidence collected through APQP and validated with results from the first trial run. The trial run cannot be a prototype. This trial must represent the production environment, with correct tools, machines, 
processes, personnel and conditions that may affect part quality [http://quality-one.com/apqp/].

APQP clearly highlights project issues quickly when they are relatively easy and inexpensive to resolve.

Deming's Plan, Do, Check and Act (PDCA) is a four-step management method used in business for the control and continuous improvement of processes and products. The first three stages are devoted to the up-front development and planning. Lastly, Act is the implementation phase focusing on customer satisfaction and continual improvement. APQP practically applies PDCA to the project management process [APQP Reference Manual, 1995].

\section{A. The Necessity of APQP in Projects}

Lot of emphasis is placed on different technical approach to Design problems as they tend to be ill structured and open-ended, but attention to details of the process remain neglected. This can be largely attributed to ED problem solving process/structure being open ended [Dym, C. et al., 2005]. While helping nurture student creativity at lower semesters it can be an impediment at higher semesters and during employment especially as organisations rely on established processes and systems to deliver results [Dutson, A.J. et al., 1997]. There is a need to address this lacuna through incorporation of an industry developed framework in higher semesters of Automobile Engineering projects. This will create a uniform process throughout as students will follow an established and proven project execution structure. With the technical aspects of the project still remaining open-ended, individuality/ uniqueness of the projects can be maintained.

The same can be summarised in form of the objectives of this paper as follows

1. Primary objective: Structured process in project execution.

2. Secondary objective: Bridging the gap between industry and academia.

3. Tertiary objective: Addressing Outcome Based Education criteria.

\section{Implementation Methodology}

APQP was implemented on an undergraduate project Solar Array Electric Vehicle (SAEV) running in Electric Solar Vehicle Championship organised annually by Imperial Society of Innovative Engineers. It was for the first time that a student team was participating in this competition.

The competition is divided into two phases, Virtual round and Dynamic round. In virtual round the students have to submit only the completed design of the vehicle, once qualified they have to fabricate it and compete in Dynamic round at national level against student teams from other educational institutions [https://www.imperialsociety.in].
Keeping in mind the limitations posed in terms of resources, the complexity of incorporating all the stages and tasks of APQP only 3 stages and their respective task were selected for initial implementation as described below in table 1 .

Table 1: APQP stages finalised to be implemented and their respective
\begin{tabular}{|l|l|l|}
\hline $\begin{array}{l}\text { Sl. } \\
\text { No. }\end{array}$ & APQP Stage & Task Description \\
\hline 1 & Plan \& Define & $\begin{array}{l}\text { Problem statement, Team } \\
\text { organisation, Project } \\
\text { timeline, Market research } \\
\text { (online survey), } \\
\text { Benchmarking, Design goals, } \\
\text { Preliminary BOM }\end{array}$ \\
\hline 2 & $\begin{array}{l}\text { Product Design \& } \\
\text { Development }\end{array}$ & $\begin{array}{l}\text { DFMEA, DVP, Design for } \\
\text { manufacturability and } \\
\text { assembly, list of engineering } \\
\text { and material specs, CAD and } \\
\text { analysis }\end{array}$ \\
\hline 3 & $\begin{array}{l}\text { Feedback \& Corrective } \\
\text { actions }\end{array}$ & $\begin{array}{l}\text { Check design adherence to } \\
\text { rules and goals set in Stage 1 }\end{array}$ \\
\hline
\end{tabular}

\section{Results and Discussions}

The application of APQP streamlined the project. The competition required the students to design the vehicle keeping commercialisation in mind. Hence the design was based on potential customer inputs and the changes and problems in design were identified early in the process. Also, an early planning was ensured for the complete design process.

The team SAEV successfully implemented all the stages and tasks outlined in table 1 and were also able to carry out an addition step in terms of Control Plan Methodology after the completion of the project. Details of important tasks of each stage are highlighted in the following sections as example.

\section{A. Plan \& Define Program}

High emphasis was placed on this stage as it would be the foundation for the following stages. A problem statement was developed, project timeline and team was organized (Fig. 1 and Fig. 2), team carried out a market research and analysis on customer needs and requirement through an online survey (Fig. 3), benchmarking was done considering similar competition vehicles and the results of previous year, design goals were established (table 2), preliminary bill of materials was listed out.

\section{B. Product Design \& Development}

Inputs derived from the outputs of the first stage were used for DFMEA (Design Failure Mode Effect Analysis) extract of which is shown in table 4, Design for Manufacturability and Assembly, DVP (Design Validation Plan) as in table 3, along with the listing of engineering \& material specifications, CAD (Computer Aided Design) drawings and technical validations of the SAEV. 


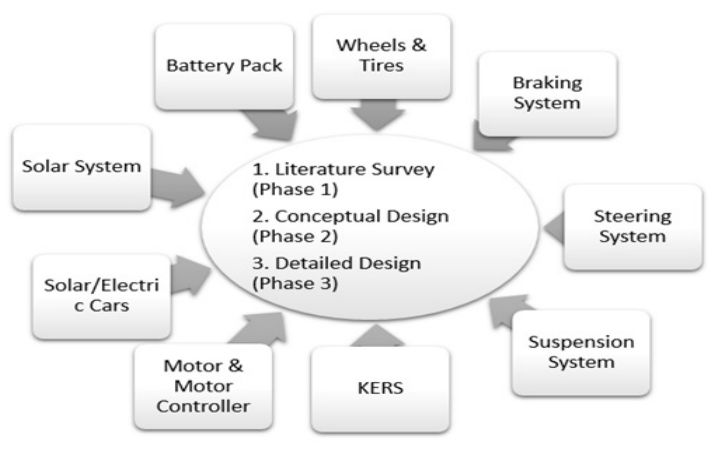

Fig 1.Work distribution (Design phase)

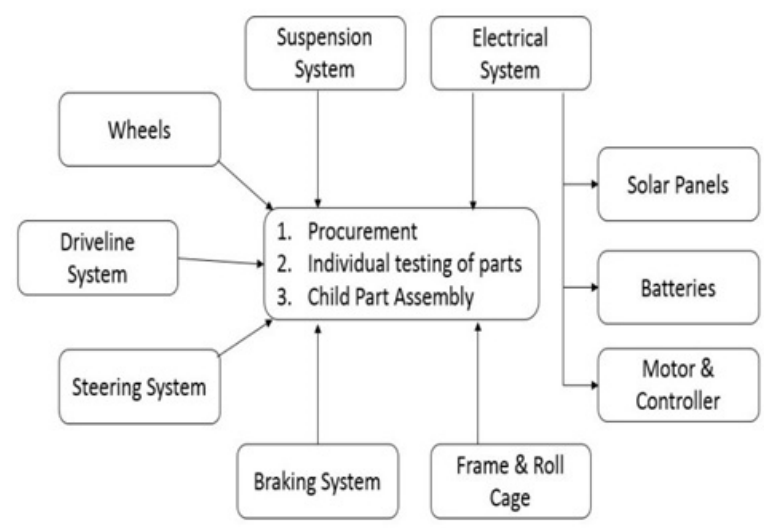

Fig 2.Work distribution (Fabrication phase)

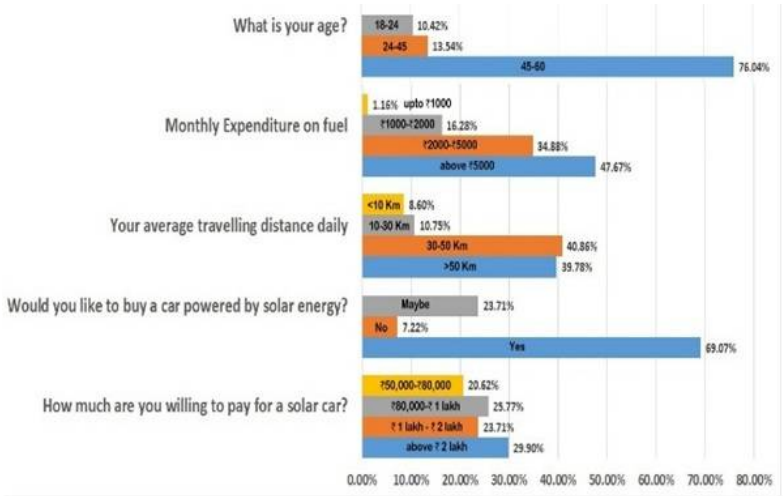

Fig 3. Extract of marketing survey results

Table 2: Extract of Design goals set and achieved

\begin{tabular}{|c|c|c|}
\hline $\begin{array}{l}\text { Sl. } \\
\text { No. }\end{array}$ & Design Goals Set & Design Goals Achieved \\
\hline 1 & $\begin{array}{l}\text { Light weight frame (under } \\
45 \mathrm{~kg} \text { ) }\end{array}$ & $35 \mathrm{Kg}$ \\
\hline 2 & $\begin{array}{l}\text { Design to achieve high } \\
\text { power to weight ratio }\end{array}$ & $\begin{array}{l}6.6 \mathrm{~W} / \mathrm{kg}(1 \mathrm{~kW} / 150 \mathrm{~kg}) \\
\text { highest in the entire } \\
\text { competition }\end{array}$ \\
\hline 3 & $\begin{array}{l}\text { Design to achieve max. } \\
\text { Surface area for solar } \\
\text { panels }\end{array}$ & $2.5 \mathrm{~m}^{2}$ \\
\hline 4 & $\begin{array}{l}\text { Battery pack weight below } \\
10 \mathrm{~kg}\end{array}$ & $\begin{array}{l}9.2 \mathrm{~kg} \text { (Lowest in the } \\
\text { entire competition) }\end{array}$ \\
\hline
\end{tabular}

\section{Feedback and Corrective Actions}

The specifications of the developed design were matched with the rules and regulations laid down for the technical specifications of the vehicle by ESVC committee and corrective actions were taken. Example: The initial electric motor chosen was $600 \mathrm{~W}$ but as the power to weight ratio suffered, a $1 \mathrm{~kW}$ motor was selected and this change was within the framework of the rules provided.

\begin{tabular}{|c|c|c|c|c|c|}
\hline $\begin{array}{l}\text { SI } \\
\text { No }\end{array}$ & Test & $\begin{array}{l}\text { Test } \\
\text { Method }\end{array}$ & $\begin{array}{l}\text { Acceptan } \\
\text { ce } \\
\text { Criteria }\end{array}$ & $\begin{array}{l}\text { Assigne } \\
\text { d Team } \\
\text { Membe } \\
\text { r }\end{array}$ & $\begin{array}{l}\text { Test } \\
\text { Result }\end{array}$ \\
\hline 1 & $\begin{array}{l}\text { Braking } \\
\text { from } \\
50 \mathrm{kmph}\end{array}$ & $\begin{array}{l}\text { Theoreti } \\
\text { cal }\end{array}$ & $\begin{array}{l}\text { Stopping } \\
\text { distance } \\
\text { not more } \\
\text { than } 5 \mathrm{~m}\end{array}$ & $\begin{array}{l}\text { Roshan, } \\
\text { Mahesh }\end{array}$ & $\begin{array}{l}\text { Stoppi } \\
\text { ng } \\
\text { distan } \\
\text { ce } \\
4.43 \mathrm{~m}\end{array}$ \\
\hline 2 & Battery & $\begin{array}{l}\text { Laborat } \\
\text { ory }\end{array}$ & $\begin{array}{l}\text { Individual } \\
18650 \text { cell } \\
\text { should } \\
\text { produce } \\
\text { not less } \\
\text { than } 3 \mathrm{~V}, 2 \\
\text { Ah }\end{array}$ & $\begin{array}{l}\text { Venkatr } \\
\text { ao } \\
\text { Abhinav } \\
\text { K Rahul }\end{array}$ & $\begin{array}{l}3.7 \mathrm{~V}, \\
2.2 \mathrm{Ah}\end{array}$ \\
\hline 3 & $\begin{array}{l}\text { Solar } \\
\text { Panel }\end{array}$ & $\begin{array}{l}\text { Laborat } \\
\text { ory }\end{array}$ & $\begin{array}{l}\text { Power } \\
\text { output } \\
\text { should not } \\
\text { be less } \\
\text { than } \\
\text { 200W }\end{array}$ & $\begin{array}{l}\text { Akshay, } \\
\text { Rejin }\end{array}$ & $250 \mathrm{~W}$ \\
\hline 4 & Material & $\begin{array}{l}\text { Laborat } \\
\text { ory }\end{array}$ & $\begin{array}{l}\text { Required } \\
\text { yield } \\
\text { strength : } \\
\text { more than } \\
400 \mathrm{MPa}\end{array}$ & $\begin{array}{l}\text { Charles, } \\
\text { Rahul T }\end{array}$ & $\begin{array}{l}465 \\
\mathrm{MPa}\end{array}$ \\
\hline 5 & $\begin{array}{l}\text { Suspens } \\
\text { ion }\end{array}$ & $\begin{array}{l}\text { Theoreti } \\
\text { cal }\end{array}$ & $\begin{array}{l}\text { Min. } \\
\text { suspensio } \\
\text { n travel: } 2 \\
\text { inch }\end{array}$ & $\begin{array}{l}\text { Manjun } \\
\text { ath, } \\
\text { Pradeep }\end{array}$ & 5 inch \\
\hline 6 & Steering & $\begin{array}{l}\text { Theoreti } \\
\text { cal }\end{array}$ & $\begin{array}{l}\text { Turning } \\
\text { Radius: } \\
2 \mathrm{~m}-5 \mathrm{~m}\end{array}$ & $\begin{array}{l}\text { Akshay, } \\
\text { Rejin }\end{array}$ & $2.95 \mathrm{~m}$ \\
\hline
\end{tabular}

\section{Control Plan Methodology}

A written description of the system for controlling parts \& processes was carried out, which will be a reference for quality planning for future development in design of the SAEV. Table 5 shows an extract of the lessons learnt and their corresponding plan developed for the next vehicle.

Errors being identified in the design stage also ensured reduced variations between the design and actual product along with faster fabrication/production time. Fig. 5 and Fig. 6 highlight the CAD model and completed vehicle, the camparison of which shows meticulous work during the design phase and attainment of the same through manufacturing.

Also worth noting is the stage of Control Plan Methodology. Through implementation of this stage we 
can ensure continuous improvement process, something that is missed out in ED projects. This was done at $3 \mathrm{rd}$ year level and laid a strong platform for visualising better implementation of capstone projects.

\section{Conclusion}

Students imbibed APQP for the transformation of initial idea into real solar vehicle. Though the milestones covered in this process were many, but the emphasis was more on the objectives stated earlier. The following section discusses the major objectives achieved from this process.

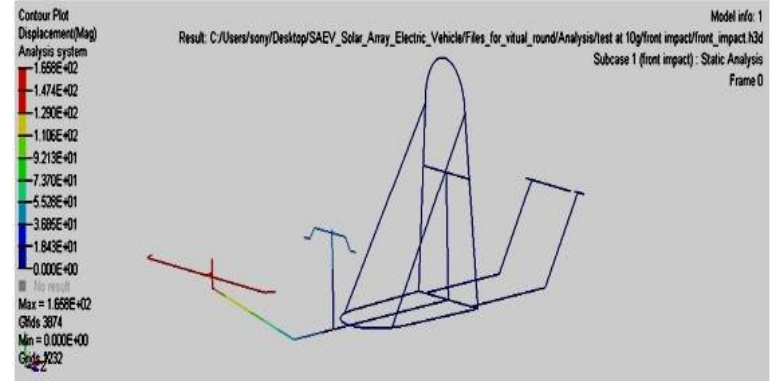

Fig 4: Front impact analysis

Table 4: Extract of DFMEA of electrical system

\begin{tabular}{|c|c|c|c|c|c|c|c|c|c|c|c|}
\hline Sl. No. & $\begin{array}{c}\text { Item } \\
\text { Identification }\end{array}$ & Function & $\begin{array}{l}\text { Failure } \\
\text { Mode }\end{array}$ & $\begin{array}{c}\text { Failure } \\
\text { Cause }\end{array}$ & Occurance & $\begin{array}{c}\text { Failure Effect On } \\
\text { Component/Functional } \\
\text { Assembly/Systema }\end{array}$ & Severity & $\begin{array}{l}\text { Failure } \\
\text { Detection } \\
\text { Method }\end{array}$ & Detection & $\begin{array}{l}\text { RPN(Risk } \\
\text { Priority } \\
\text { No.) }\end{array}$ & $\begin{array}{l}\text { Corrective } \\
\text { Measure }\end{array}$ \\
\hline 1 & Solar Panel & $\begin{array}{l}\text { Battery } \\
\text { Charging }\end{array}$ & $\begin{array}{l}\text { faulty } \\
\text { connectio } \\
n\end{array}$ & $\begin{array}{l}\text { Sudden } \\
\text { Impact }\end{array}$ & 1 & Battery Charging & 1 & $\begin{array}{l}\text { No battery } \\
\text { Charging }\end{array}$ & 1 & 1 & $\begin{array}{l}\text { Rigid support } \\
\text { structure/ } \\
\text { Well } \\
\text { insulated and } \\
\text { tightly fitted } \\
\text { wirings } \\
\end{array}$ \\
\hline 2 & Battery & \begin{tabular}{|l|} 
Power \\
Storage/So \\
urce for \\
motor
\end{tabular} & $\begin{array}{l}\text { Deep } \\
\text { Discharge } \\
\text { /Overchar } \\
\text { ge }\end{array}$ & $\begin{array}{l}\text { MPPT } \\
\text { failure }\end{array}$ & 2 & Motor & 2 & $\begin{array}{l}\text { Motor } \\
\text { disfuction }\end{array}$ & 1 & 4 & $\begin{array}{l}\text { Use of good } \\
\text { quality MPPT }\end{array}$ \\
\hline 3 & Motor & $\begin{array}{l}\text { Prime } \\
\text { mover }\end{array}$ & $\begin{array}{l}\text { faulty } \\
\text { connectio } \\
\text { n }\end{array}$ & $\begin{array}{l}\text { Mechanic } \\
\text { al } \\
\text { Vibrations }\end{array}$ & 3 & Transmission System & 2 & $\begin{array}{l}\text { No vehicle } \\
\text { motion }\end{array}$ & 1 & 6 & $\begin{array}{l}\text { Properly } \\
\text { insulated and } \\
\text { fixed } \\
\text { connections }\end{array}$ \\
\hline 4 & Battery & \begin{tabular}{|l|} 
Power \\
Storage/So \\
urce for \\
motor
\end{tabular} & $\begin{array}{l}\text { Short } \\
\text { Circuit/bu } \\
\text { rst } \\
\end{array}$ & $\begin{array}{l}\text { improper } \\
\text { insulation }\end{array}$ & 1 & Battery Pack & 4 & & 1 & 4 & $\begin{array}{l}\text { Proper } \\
\text { insulation/ } \\
\text { using good } \\
\text { quality wires }\end{array}$ \\
\hline 5 & MPPT & \begin{tabular}{|l|} 
\\
Current \\
Stabilizing
\end{tabular} & $\begin{array}{l}\text { Not able } \\
\text { to } \\
\text { stabilize } \\
\text { the } \\
\text { current }\end{array}$ & $\begin{array}{l}\text { Heating/ } \\
\text { Short } \\
\text { circuit }\end{array}$ & 1 & Battery & 2 & $\begin{array}{l}\text { No battery } \\
\text { Charging }\end{array}$ & 1 & 2 & $\begin{array}{l}\text { Air duct for } \\
\text { proper } \\
\text { cooling }\end{array}$ \\
\hline
\end{tabular}

Table 5: Extract of Control Plan Methodology chart

\begin{tabular}{|c|c|c|c|c|}
\hline Sl. No. & $\begin{array}{l}\text { Process or part } \\
\text { Name/ Operation } \\
\text { Description }\end{array}$ & Problems Encountered & Control Plan & Reaction Plan \\
\hline 1 & Frame & $\begin{array}{l}\text { Excess Weight of Procured } \\
\text { Material/Overdesigned Frame }\end{array}$ & $\begin{array}{l}\text { Use of different c/s for frame } \\
\text { material }\end{array}$ & $\begin{array}{l}\text { Intense analysis of designed } \\
\text { frame and optimization of frame } \\
\text { c/s to be used in the Designing } \\
\text { phase itself }\end{array}$ \\
\hline 2 & $\begin{array}{l}\text { Material Cut angles } \\
\text { for joining process }\end{array}$ & $\begin{array}{l}\text { Mismatched cut angles } \\
\text { influencing improper welding }\end{array}$ & $\begin{array}{l}\text { Proper developments for cut } \\
\text { angles }\end{array}$ & $\begin{array}{l}\text { Proper calculation of cut angles } \\
\text { and considering welding } \\
\text { processes in the designing phase }\end{array}$ \\
\hline 3 & Driver seat & $\begin{array}{l}\text { Uncomfortable entry \& exit/ } \\
\text { Longer entry \& exit time }\end{array}$ & Modification of driver's seat & $\begin{array}{l}\text { Frame modification required at } \\
\text { the driver's compartment/ To be } \\
\text { carried out during designing } \\
\text { phase }\end{array}$ \\
\hline 4 & Impact Bumpers & Too high & $\begin{array}{l}\text { Repositioning of front and } \\
\text { rear bumpers }\end{array}$ & 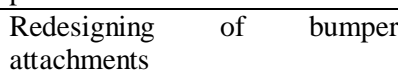 \\
\hline
\end{tabular}




\section{- $\quad$ Primary Objective}

Through implementation of APQP the student team had a clear idea of the tasks that needed to be completed at the respective stages of the project development. This is clearly evident from the data mentioned in the previous sections.

\section{- Secondary Objective}

Many Indian and multi-national companies based in India like Mahindra \& Mahindra, Tata Motors Limited, BorgWarner Inc and DivgiWarner Private Limited etc...follow APQP. Implementation of APQP at undergraduate project level will ensure industry process ready engineers from our educational institutes along with creating higher placement opportunities for students.

\section{- Tertiary Objective}

The authors would like to underscore the achievements in competencies, Abet criteria $3 \mathrm{~d}$ and $3 \mathrm{e}$, which deal with the student's ability to function in multidisciplinary teams and his ability to identify, formulate and solve automotive engineering problems respectively.

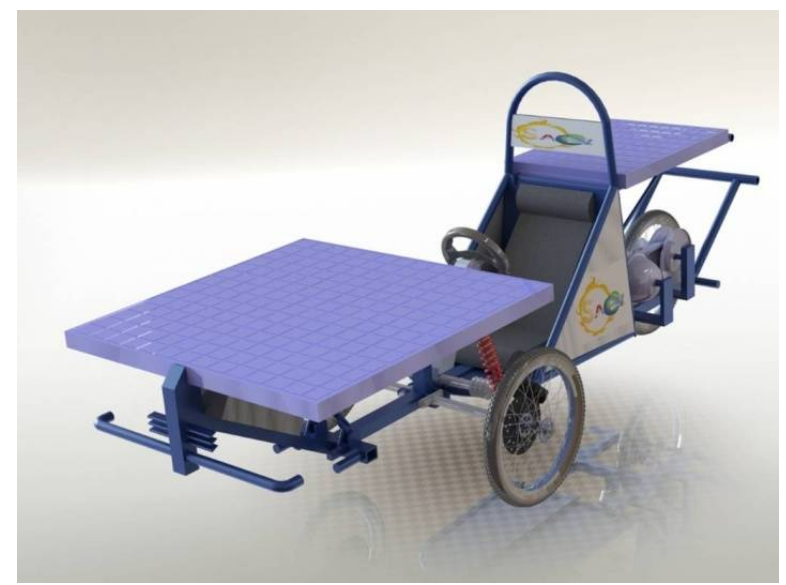

Fig. 5: CAD model of the vehicle after APQP stage 2

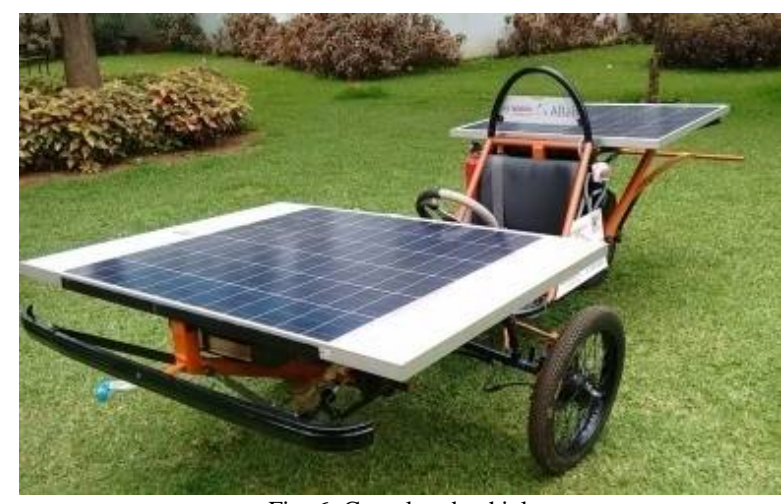

Fig. 6: Completed vehicle

\section{References}

[1] Advanced Product Quality Planning (APQP) and Control Plan, Reference Manual, Copyright 1994, 1995. Chrysler Corporation, Ford Motor Company and General Motors Corporation.

[2] http://quality-one.com/apqp/ (last accessed $30 / 09 / 2015)$

[3] Dym, Alice, Ozgur, Daniel and Larry, "Engineering Design Thinking, Teaching, and Learning," Journal of Engineering Education, Vol. 94, No.1, 2005, pp. 103120.

[4] Dutson, A.J., Todd, R.H., Magleby, S.P., and Sorensen, C.D., "A Review of Literature on Teaching Design Through Project-Oriented Capstone Courses," Journal of Engineering Education, Vol. 76, No. 1, 1997,pp. 17-28.

[5] https://www.imperialsociety.in/ (last accessed 30/09/2015) 